\title{
$41: 616$
}

\section{第 46 回日本老年医学会学術集会記録}

〈若手企画シンポジウム II：老化メカニズムの解明と老化制御の最前線〉

\section{1. 老化メカニズムの解明と老化制御の最前線}

\section{白澤 卓二}

\begin{abstract}
〈要＼cjkstart約〉＼cjkstart長寿命線虫から発見された daf-2 遺伝子はインスリン受容体をコードする遺伝子であることか ら，インスリンシグナルと個体寿命の関係が研究されている. 我々は, マウスに遺伝子操作することによ り, インスリン受容体を改変したモデルマウスを作製し, 哺乳動物でもインスリンシグナルが寿命に関与 するかどうか検討した，その結果，モデルマウスは酸化ストレスに対して耐性になっていること，エスト ロゲンシグナルやカロリー制限がインスリンの長寿シグナルに影響を与えることを示唆した.
\end{abstract}

Key words：長寿命線虫，インスリン受容体，モデルマウス，エストロゲンシグナル，カロリー制限

（日老医誌 $2004 ； 41 ： 616-618$ )

\section{線虫で発見された寿命制御遺伝子}

1997 年に daf-2 長寿命線虫および $c l k-1$ 長寿命線虫か ら原因遺伝子が単離された，前者からはインスリン受容 体遺伝子, 後者からはクロック 1 遺伝子が単離され, 線 虫には個体寿命を制御するシグナルがあることが判明し た ${ }^{122)}$. 前者のシグナルはインスリンシグナルで，糖代謝 を制御しているシグナルであるのに対して，後者のシグ ナルはミトコンドリアの酸化的リン酸化を制御するシグ ナルであった.この 2 つのジナルはクロストークもあ るが，本来，別々のシグナル系を制御していると考えら れている. 実際, daf-2 と clk-1 の 2 重変異体は野生マウ スに比べて，5倍に寿命が延長する実験事実からもシグ ナルの独立性とクロストークが示唆されている3゙.

線虫のゲノムには 19,000 の遺伝子が存在することが 判明している．遺伝子数だけを論じれば，ヒトゲノムの 約 3 分の 2 の遺伝子数をカバーしていることになる.し かも，その $76 \%$ の遺伝子はヒトゲノムとの相同性を認 めている.これまでに知られているインスリンシグナル もミトコンドリアのシグナルも線虫と哺乳動物の間でよ く保存されている遺伝子である.

\section{モデルマウスの作製}

実際，ヒトのゲノム，マウスのゲノムに相同遺伝子が あることから，これらの相同遺伝子が果たして，哺乳動

Longevity signals are conserved between invertebrates and mammals

Takuji Sirasawa：東京都老人総合研究所, 分子老化研 究グループ
野生型マウスのインスリンレセプター遺伝子

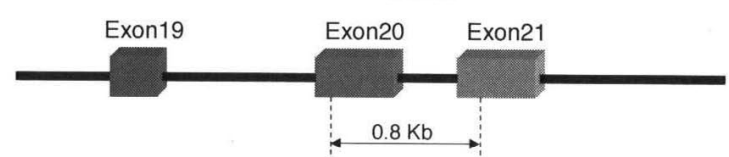

モデルマウスのインスリンレセプター遺伝子

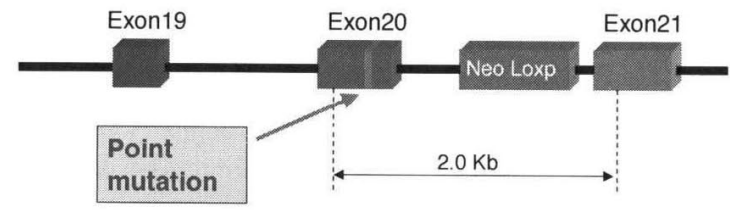

図 1 長寿命モデルマウス マウスのインスリン受容体をコードする染色体遺伝子の エタソン 20 に点突然変異を挿入し，インスリン受容体 の 1,195 番目のアミノ酸残基をプロリン (P) からロイ シン（L）に置換した.

物の個体寿命あるいはヒトの個体寿命を制御しているの か興味が持たれる点である ${ }^{4}$. 我々の研究室では, 線虫 で発見された長寿命遺伝子である daf-2 や clk-1 のマウ ス相同遺伝子に長寿命線虫と同様の変異を導入して, マ ウスの寿命が線虫のように延長できるのかどうか実証す るための研究を行っている，そのためにマウスのゲノム 遺伝子を改変した寿命遺伝子改変マウスを作製してモデ ルマウスの解析を行っている.

今回紹介するインスリン受容体改変マウスはマウスの インスリン受容体遺伝子エクソン 20 に長寿命線虫で発 見された遺伝子辺を導入することにより作製したモデル である（図 1)。作製されたマウスは両側の染色体遺伝 子に変異が導入された場合 (ホモ接合体), 完全にイン 


\section{Survival of Insulin Receptor Mutant Mice under 80\% Oxygen Exposure}
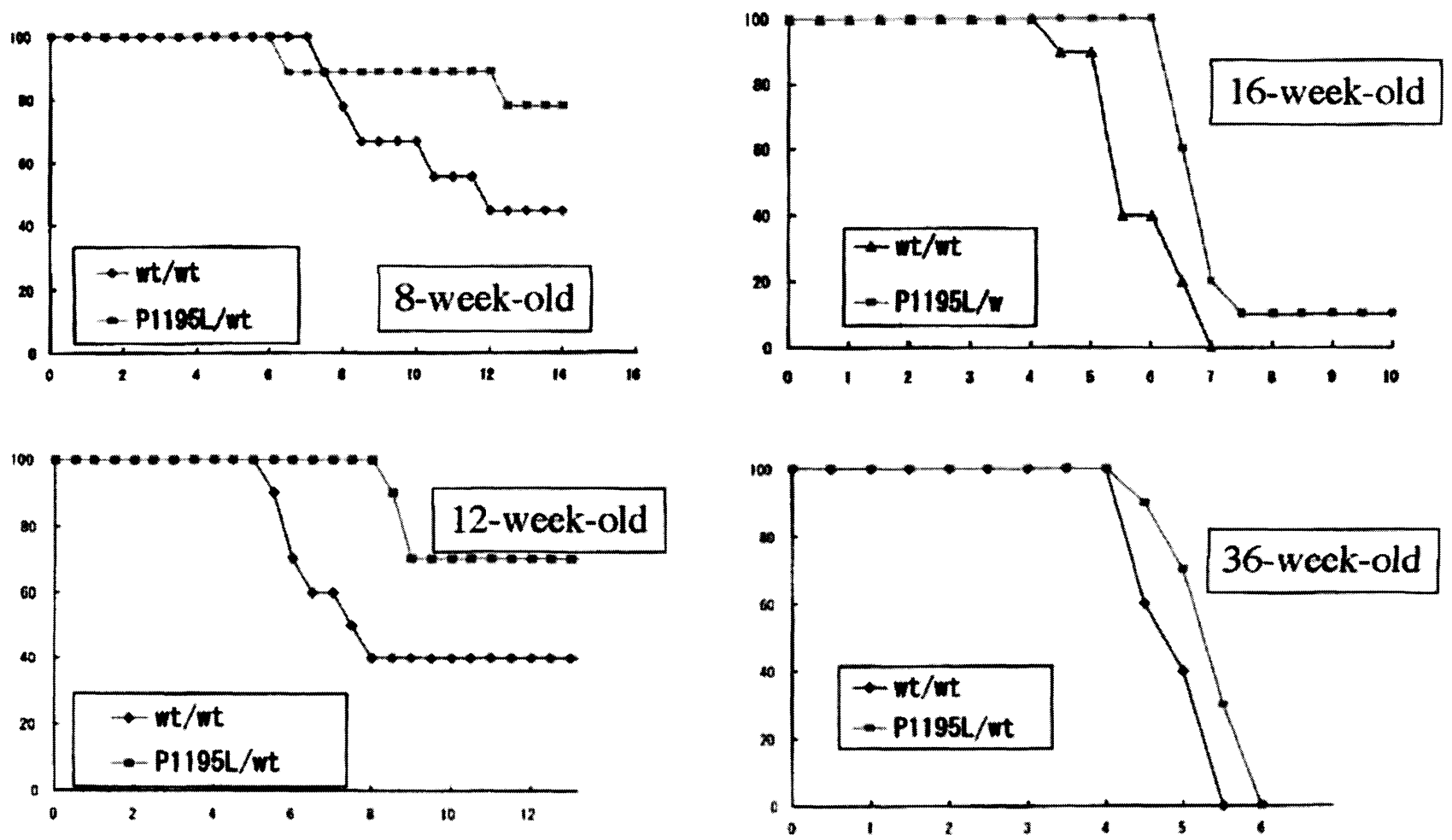

図 2 インスリン受容体改変マウス（IR 変異マウス）は酸化ストレスに対して耐性である 8 週齢, 12 週齢, 16 週齢, 36 週齢の IR 変異マウスを酸化ストレス条件である $80 \%$ 酸素チェンバー で飼育すると，野生マウスより長生きである.

スリンシグナルを欠失している，そのため，生直後に重 症の糖尿病を発症し, 最終的には 48 時間以内に糖尿病 性ケトアシドーシスで死亡することが判明した。この事 実から，寿命制御シグナルの完全なノックアウトは哺乳 動物では糖尿病という病態をもたらすことが判明した。 それでは, なぜ, 線虫は糖尿病にならずに長寿を達成で きたのだろうか？ 最も単純な答えは，線虫には䐙蔵が 無いので，糖尿病を発症しえないという事実である。一 方で，インスリンの果たす生物学的役割が哺乳動物では 糖代謝が中心的であるのに対し, 線虫などの無脊椎動物 では，飢餓状態におかれた時に個体を耐性幼虫化するシ グナルを制御しているという大きな違いがある。いずれ にせよ，ホモ接合体は個体寿命の実験には使用できない ことが判明. 我々は，へテロ接合体のミュータントマウ スを以下の実験に使用することにした。

\section{モデルマウスにおける 酸化ストレス耐性と SOD 活性}

図 2 に変異マウスの酸化ストレス耐性をグラフに示し てある（四 2)，我々はマウスを $80 \%$ 酸素条件で飼育す ることにより酸化ストレスに対する抵抗性を調べた。最 終的にマウスはチェンバー内で飼育すると， 2 週間以内 に呼吸不全で死亡した，死亡時にマウスの肺の組織を顕 微鏡で観察すると,肺の間質に激しい細胞浸潤を認めた。 更に肺胞には硝子膜が形成され呼吸不全の病理は明らか で, マウスは呼吸不全で死亡していると診断された.

図 1 のデー夕を見るとミュータントマウスの酸化スト レス耐性能は若齢ほど強い傾向が示される。つまり, 若 いミュータントマウスほど, 酸化ストレスにより強い傾 向が認められる。

加齢とともに酸化ストレスに対して弱くなる傾向が明 


\section{Estrogen treatment}

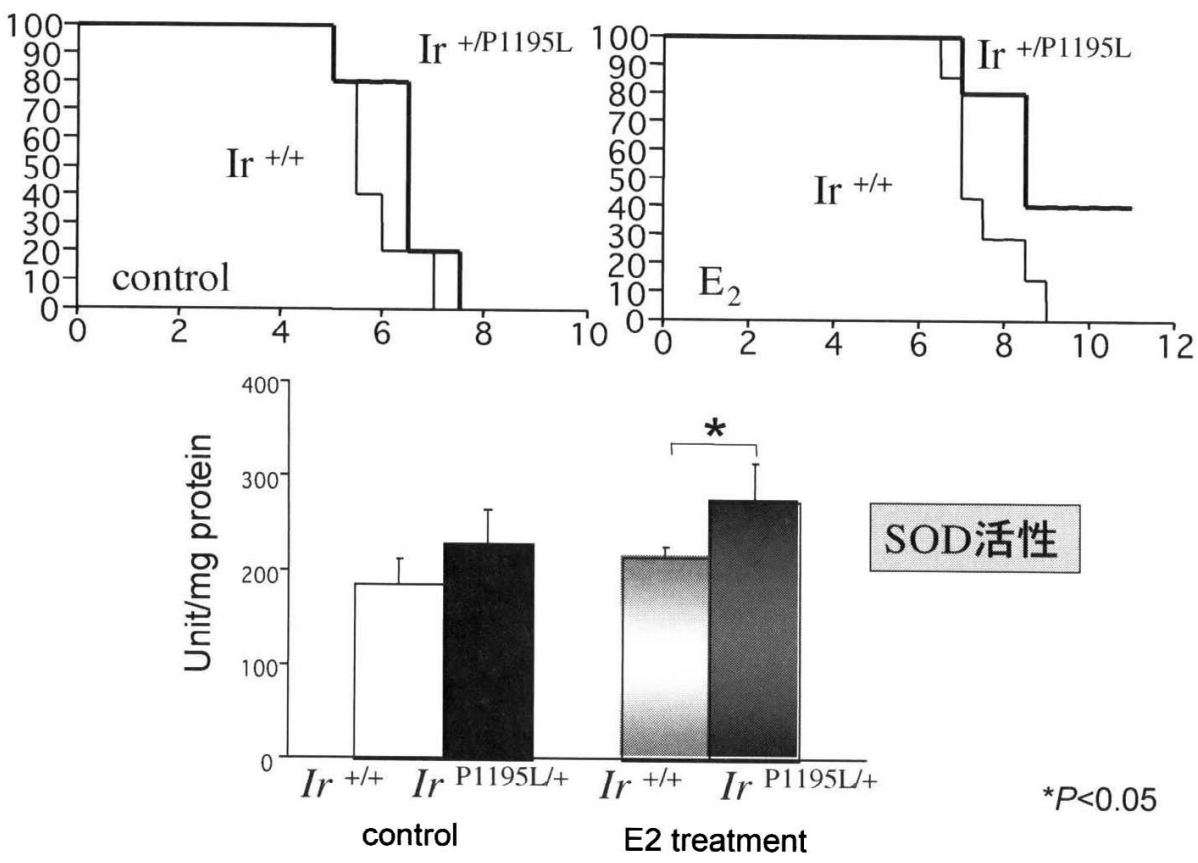

図 3 IR 変異マウス（オス）は 80\% 酸素チェンバー内で長寿命を示すが，エストロゲンを投与する と更に長寿命を呈する (上段). 肝蔵では SOD 活性が立進している (下段).

らかとなった.しかし、その詳細なメカニズムに関しては 不明である．年をとると酸化ストレス自体が増強するた めに本来の遺伝学的有利性つまり遺伝子的に獲得された 抗酸化ストレスの防御メカニズムの効果が打ち消されて しまう可能性がある。実際，変異マウスの肝臓に押ける SOD 活性は上昇していて, 变異マウスの酸化ストレスに 対する耐性が増強した理由の1つとなっている(図 3)。

\section{酸化ストレス耐性とエストロゲンシグナル}

我々は更に雄のマウスと雌のマウスでは酸化ストレス 条件下での寿命に差があることを見いだした．雌の変異 マウスは雄よりも酸化ストレスに対して強いことを見い だした

そこで我々はエストロゲンの作用により，雌の個体寿 命が延長している可能性を検討する目的で，雄の変異マ ウスにエストロゲンを投与し，個体寿命に与える影響を 検証してみた，予想通り，エストロゲンを投与された雄 の変異マウスおよび雄の野生型マウスはいずれも酸素 チェンバー内で長寿命を示した (図 3, 右上)。肝臓にお ける SOD 活性が上昇していることから，エストロゲン 投与による寿命延長効果は SOD の活性が重要であるこ とが示された（図 $3, 下)$.これらの寒験からエストロゲ
ンが寿命を制御しているインスリンシグナルに影響を与 えていることが判明した.これらの実験から示されたよ うに, 細胞内シグナルは複雑で，インスリンシグナルは エストロゲンシグナルとクロストークがあることが示さ れた。

\section{文献}

1) Kimura KD, Tissenbaum HA, Liu Y, Ruvkun G : daf-2, an insulin receptor-like gene that regulates longevity and diapause in Caenorhabditis elegans. Science $1997 ; 277$ : $942-946$.

2) Ewbank JJ, Barnes TM, Lakowski B, et al. : Structural and functional conservation of the Caenorhabditis elegans timing gene clk-1. Science $1997 ; 275: 980-983$.

3) Honda $Y$, Honda $S$ : The daf-2 gene network for longevity regulates oxidative stress resistance and $\mathrm{Mn}$ superoxide dismutase gene expression in Caenorhabditis elegans. Faseb J $1999 ; 13: 1385-1393$.

4) Nakai D. Yuasa S, Takahashi M, Shimizu T, Asaumi S, Isono K, et al. : Mouse Homologue of $\operatorname{coq} 7 / \mathrm{clk}-1$, Longevity Gene in Caenorhabditis elegans, Is Essential for Coenzyme Q Synthesis, Maintenance of Mitochondrial Integrity, and Neurogenesis. Biochem Biophys Res Commun $2001 ; 289: 463-471$. 